\title{
Analisis Pemahaman Matematis Siswa Melalui Metode Demonstrasi
}

\author{
Syaima Hany Yuliana ${ }^{1 *}$, Astri Sutisnawati ${ }^{2}$, Dyah Lyesmaya ${ }^{3}$. \\ ${ }^{1}$ Universitas Muhammadiyah Sukabumi, Indonesia \\ 2 Universitas Muhammadiyah Sukabumi, Indonesia \\ 3 Universitas Muhammadiyah Sukabumi, Indonesia \\ *Corresponding author: simahany0510@ummi.ac.id
}

\begin{abstract}
The low value of this evaluation test can be caused by the lack of a concrete explanation given by the teacher. Besides that, the learning plans, teaching aids, methods and evaluation tools prepared by the teacher must be better than before, in an effort to further improve the success of students' learning influenced by several factors from within and from outside students, for example from within students including intelligence, learning strategies, motivation and so on. The type of research used isqualitative research a case study, because the results of this research are descriptive analysis in the form of written or spoken words from the observed behavior, especially related to how the demonstration method can increase the mathematical ability of the subject in this study is class II. SDN Tegalpari with the technique used by researchers is to analyze data using techniques, interviews, observation and also documentation. Based on the results of qualitative research that has been carried out using interview techniques and also observations to class teachers and also class II students at SDN Tegalpari about analyzing students' mathematical understanding through this demonstration method, it can be concluded that learning using this demonstration method cannot be said to be effective because the results are still very minimal. for students to fully understand the mathematical material.
\end{abstract}

Keywords: demonstration; mathematical understanding

\section{ABSTRAK}

Rendahnya nilai tes evaluasi ini dapat disebabkan karena kurangnya penjelasan yang konkrit yang disampaikan oleh guru. Disamping itu rencana pembelajaran, alat peraga, metode dan alat evaluasi yang dipersiapkan guru harus lebih baik dari sebelumnya, dalam upaya untuk lebih meningkatkan keberhasilan pembelajaranya siswa di pengaruhi beberapa faktor dari dalam maupun dari luar diri siswa contohnya dari dalam diri siswa mencakup kecerdasan, strategi pembelajaran, motivasi dan sebagainya. Jenlis penelitaian yang digunakan adalah penelitian kualitatif studi kasus, karena maka hasil dari penelitian ini bersifat analisis Deskriptif yaitu berupa kata-kata tertulis atau lisan dari perilaku yang di amati terutama terkait dengan bagaimana metode demonstrasi dapat menambah kemampuan matematis subjek dalam penelitian kali ini adalah kelas II SDN Tegalpari dengan teknik yang digunakan peneliti adalah dengan analisis data menggunakan tenik, wawancara, observasi dan juga dokumentasi.Berdasarkan hasil penelitain kualitatif yang telah dilakukan dengan menggunakan teknik wawancara dan juga observasi kepada guru kelas dan juga siswa kelas II SDN Tegalpari tentang analisis pemahaman matematis siswa melalui metode demonstrasi ini dapat disimpulkan pebelajaran menggunakan metode demonstrasi ini belum bisa dikatakan efektif karna hasil nya masih sangat minim unuk siswa paham bentul terhadap materi matematika.

Kata kunci: demonstrasi; pemahaman matematis

\section{Pendahuluan}

Pendidikan dasar ialah dimana untuk memberikan pengetahuan dan juga keterampilan, menumbuhkan sikap dasar yang diperlukan dalam bermasyarakat, serta untuk mempersiapkan peserta didik dalam mengikuti pendidikan menengah. Pendidikan dasar ini diselenggarakan untuk memberikan bekal mendasar yang diperlukan untuk hidup dalam bermasyarakat berupa pengembangan sikap, pengetahuan dan juga keterampilan dasar. Pendidikan dasar disebut Sekolah Dasar (SD) yaitu lembaga pendidikan yang menyelenggarakan program pendidikan sebagai dasar untuk mempersiapkan siswanya yang 
melanjutkan ataupun tidak pelajarannya ke lembaga pendidikan yang lebih tinggi, untuk menjadi warga negara yang baik. Adapun pengertian pendidikan dasar yang termasuk dalam Undang - Undang sistem pendidikan Nasional BAB VI Pasal 17 menyebutkan bahwa pertama, pendidikan dasar merupakan jenjang pendidikan yang melandasi jenjang pendidikan menengah. Kedua, pendidikan dasar yang berbentuk Sekolah Dasar (SD) dan Madrasah Ibtidaiyah (MI) atau dalam bentuk lain yang sederajat dan juga Sekolah Menengah Pertama (SMP) ataupun Madrasah Tsanawiyah (MTS) atau bentuk lain yang sederajat. Dalam pendidikan tersebut akan terjadi peletakan dasar dari pembangunan manusia. Esensi pada pendidikan yang dialami oleh manusia pada permulaan hidup lebih ditekankan pada fakta dan juga membaca Fakta - Fakta dalam pergelaran obyektifitas di alam ini. Begitu juga dalam pendidikan dasar tersebut orang tua tidak boleh bertengkar atau berbuat apa saja yang belum pantas untuk diketahui oleh sang anak, oleh sebab hal itu akan merusak sistem dan suasana hati yang sedang dibangun, karena alam ini tertib, maka rumah tangga serta lingkungannya harus tertib juga.

Adapun pengertian pendidikan yang tertuang dalam Undang-Undang Sisdiknas tersebut menjelaskan bahwa pendidikan sebagai proses yang di dalamnya seseorang belajar untuk mengetahui, mengembangkan kemampuan, sikap dan bentuk-bentuk tingkah laku lainnya untuk menyesuaikan dengan lingkungan di mana dia hidup.

Hal ini juga sebagaimana yang dinyatakan oleh Muhammad Saroni (2011: 10) bahwa, "pendidikan merupakan suatu proses yang berlangsung dalam kehidupan sebagai upaya untuk menyeimbangkan kondisi dalam diri dengan kondisi luar diri. Proses penyeimbangan ini merupakan bentuk survive yang dilakukan agar diri dapat mengikuti setiap kegiatan yang berlangsung dalam kehidupan."

Keunggulan dari metode demonstrasi adalah siswa dapat memusatkan perhatiannya pada pokok bahasan yang akan didemonstrasikanya, siswa juga bias memperoleh pengalaman yang dapat membentuk ingatan yang kuat ketika pembelajaran menggunakan metode ini, siswa pun bisa terhindar dari kesalahan dalam mengambil suatu kesimpulan, pertanyaanpertanyaan yang timbul dapat dijawab sendiri oleh siswa pada saat dilaksanakannya demonstrasi, apabila terjadi keraguan siswa dapat menanyakan secara langsung kepada guru, kesalahan yang terjadi dari hasil metode ceramah dapat diperbaiki karena siswa langsung diberikan contoh konkretnya dalam metode ini.

Hal ini sesuai dengan pendapat Djamarah (2011:16) yang menyatakan bahwa keunggulan metode demonstrasi adalah "membantu anak didik memahami dengan jelas jalannya suatu proses atau kerja suatu kegiatan pembelajaran, memudahkan berbagai jenis penjelasan, kesalahan- kesalahan yang terjadi dari hasil ceramah dapat diperbaiki melalui pengamatan dan contoh konkret dengan menghadirkan objek sebenarnya".

Adapun indikator dari kemampuan pemahaman matematis Menurut KillPatrick dan Findell adalah pertama, mampu menyatakan ulang konsep yang telah dipelajari. Kedua, mampu mengklasifikasikan objek-objek berdasarkan dipenuhi atau tidaknya persyaratan yang membentuk konsep tersebut. Ketiga, mampu mengaitkan beragai konsep matematika. Keempat, mampu menerapkan konsep dalam berbagai macam bentuk repsentasi matematika. 


\section{Metode Penelitian}

Jenis penelitian ini adalah studi kasus, karena penelitian ini menggunakan pendekatan kualitatif dan termasuk penelitian studi kasus maka hasil dari penelitian ini bersifat analisisDeskriptif yaitu berupa kata-kata tertulis atau lisan dari perilaku yang di ammati terutama terkait dengan bagaimana metode demonstrasi dapat menambah kemampuan matematis siswa kelas rendah di SDN Tegalpari.

Penelitian ini dilakukan di SD Negeri Tegalpari dengan siswa yang kurang akan pemahaman matematis di kelas maupun di luar kelas, SDN Tegalpari Jl. Gotong Royong No. 11 kecamatan gunung puyuh kota sukabumi jawabarat. Alasan penelitian berada di sekolah itu karna penulis ingin meningkatakan hasil belajar siswa yang berada sdi SDN Tegal pari. Waktu penelitian dilaksanakan pada tahun ajaran kedua 2020/2021 yakni terhitung mulai dari April 2021 sampai dengan selesai

Pada penelitian kali ini penulis menggunakan metode kualitatif dengan menarik data, menggunakan metode wawancara, observasi dan juga dokumentasi. Analisis data merupakan suatu proses untuk menvari dan mendata secara sistematis catatan hasil dari observasi, wawancaea, dan studi dokumentasi, untuk meningkatkan penelitian yang teliti (Bogdan dan Biklen dalar: Ajat Rukajat, 2018: 51).

Dalam sebuah penelitian kualitatif analisis data ini dilqaksanakan secara terus menerus ketika sebekum pengumpulan data di lapangan. Aktivitas dalam analisis data kualitatif dilaksanakan secara interaktif dan terus menerus samapat tuntas sehingga datanya sudah mencapai jenuh, aktivitas dalam analisis data ialah, Reduksi data (data reduction), penyajian data (data display), verifikasi /verification.

\section{Hasil dan Pembahasan}

Berdasarkan hasil wawancara dan juga observasi yang diginakan oleh penulis bahwa dapat disimpulkan bahwa pemahaman matematis siswa melalui metode demonstrasi masih tidak begitu efektif bakhan belu mencapai $85 \%$ siswa sudah mampu paham akan pembelajaran matematika tersebut dilihat dari angket yang penulisberikan melalui Whastapp grup

Tabel 1. Data Nilai Siswa

\begin{tabular}{clcc}
\hline No & & Nama siswa & Nilai siswa \\
\hline 1 & Akmal & 65 \\
2 & Ashila & 60 \\
3 & Diani & 75 \\
4 & Najma & 55 \\
5 & Noeraini & 60 \\
6 & İsa & 80 \\
7 & Dzulfa & 60 \\
8 & Aufa & 65 \\
9 & İqbal & 70 \\
10 & Ayesya & 60 \\
\hline
\end{tabular}

Begitu juga yang dirasakan oleh siswa kelas II SDN Tegal Pari. Hal tersebut diketahui dari hasil observasi awal yang dilakukan oleh penulis terhadap hasil belajar siswa pada 
matematika. Permasalahannya diperkuat setelah dilakukan tes evaluasi sebagai pratindakan pada pembelajaran matematika yang hasilnya ternyata belum mencapai Kriteria Ketuntasan Minimal (KKM).

Berdasarkan hasil uji coba penulis, bahawa hasil menunjukkan siswa yang tuntas pada pratindakanya hanya beberapa orang siswa memperoleh presentase hanya $25 \%$ sehingga menunjukkan bahwa hanya beberapa siswa yang tuntas di atas 65 KKM. Rendahnya nilai tes evaluasi ini dapat disebabkan karena kurangnya penjelasan yang konkret yang disampaikan oleh guru. Disamping itu rencana pembelajaran, alat peraga, metode dan alat evaluasi yang dipersiapkan guru harus lebih baik dari sebelumnya, dalam upaya untuk lebih meningkatkan keberhasilan pembelajaranya siswa di pengaruhi beberapa faktor dari dalam maupun dari luar diri siswa contohnya dari dalam diri siswa mencakup kecerdasan, strategi pembelajaran, motivasi dan sebagainya. Faktor-faktor dari luar diri siswa misalnya, fasilitas belajar mengajar dan cara mengajar guru, sistem pemberian feedback (umpan balik), sebagain lainya adalah salah satu faktor dari luar diri siswa yaitu cara mengajar guru, guru pun harus menciptakan pembelajaran yang memungkinkan siswa mencapai pada tujuan pembelajaran yang telah ditetapkan secara optimal.

Keunggulan dari metode demonstrasi adalah siswa dapat memusatkan perhatiannya pada pokok bahasan yang akan didemonstrasikanya, siswa juga bias memperoleh pengalaman yang dapat membentuk ingatan yang kuat ketika pembelajaran menggunakan metode ini, siswa pun bisa terhindar dari kesalahan dalam mengambil suatu kesimpulan, pertanyaanpertanyaan yang timbul dapat dijawab sendiri oleh siswa pada saat dilaksanakannya demonstrasi, apabila terjadi keraguan siswa dapat menanyakan secara langsung kepada guru, kesalahan yang terjadi dari hasil metode ceramah dapat diperbaiki karena siswa langsung diberikan contoh konkretnya dalam metode ini. Jadi untuk hal ini penulis mempunyai maksud untuk mengetahui bagaimana saja upaya untuk meningkatkan sebuah kemampuan siswa dalam memahami materi tentang matematika melalui metode demonstrasi di kelas II sekolah dasar. Karena adanya presepsi yang mengatakan bahwa matematika sebagai pelajaran yang sulit untuk dipahami dan mungkin bisa bermula dari bagaimana cara mengajar guru yang memaksakan seorang anak didik ini untuk bisa benar-benar memahami apa yang sebetulnya peserta didik kurang pahami.

Dari hasil uji coba penulis yang diberikan kepada peserta didik terlihat bahwa siswa sangat kurang memahami dalam materi perkalian disini dapat dilihat dari hasil kerja siswa yang di kerjakan bahawa hasilnya menunjukan di bawah KKM ,dalam upaya ini peneliti ingin meningkatkan pemahaman siswa agar lebih meningkatkan keberhasilan belajar siswa khususnya mata materi pembelajaran matematika khususnya hitungan mendasar seperti, pembagian, pertambahan, pengurangan dan pembagian, bahkan bisa juga dalam bentuk diluar hitungan seperti bentuk- beruk bangun datar dan sebagiamanya di luar bentuk perhitungan, dan diantaranya dapat dilakukan melalui upaya memperbaiki proses belajar mengajar yang di gunakan guru saat pembelajaran matematika. Terlebih lagi untuk menumbuhkan lagi minat dan bakat bahkan semangat belajar siswa pada mata pelajaran matematika, pemilihan pendekatan dan metode pembelajaran yang tepat.

Pada perbaikan proses pembelajaran ini peranan guru sangat penting. Oleh karena itu juga gurupun harus lebih mampu mencari tentang stategi pembelajaran apalagi yang bisa di pandang dapat menumbuhkan minat belajar siswa atau ketertarikan siswa terhadap 
pembelajaran matematika agar mengubah persepsi terhadap kata matematika sangat sulit di pahami. Sesuai pernyataan (Febriyanto et al., 2018) bahwa pemahaman matematis dapat meningkat jika pembelajaran dilakukan dengan menarik minat siswa. Contoh permasalah yang sering ditemukan pada kelas rendah ialah mata pelajaran matematika materi perkalian dan juga pembagian yang awalnya di anggap sulit, ternyata dapat dipecahkan dengan metode demonstrasi alasanya siswa dapat lebih memahami tahapan pengerjaan yang lebih sistematis dan mudah melalui pembuktian. Pada metode ini peran guru tak lebih dari seorang fasilitator, moderator atau evaluator sementara siswa aktif berfikir di dalam pembelajaran dengan metode ini, mengkomunikasikannya, melatih nuansa demokrasi dengan menghargai pendapat orang lain.

\section{Kesimpulan}

Pada penggunaan metode demonstrasi sangat menunjang proses interaksi mengajar belajar dikelas. Keuntungan yang diperoleh adalah dengan cara metode demonstrasi yang membuat perhatian siswa lebih terpusatkan pada pelajaran yag sedang diberikan, kesalahankesalahan yang terjadi bila pelajaran diceramahkan dapat diatasi melalui pengamatan dan contoh kongkrit. Sehingga yang diterima oleh para siswa lebih mendalam dan tinggal lebih lama dalam jiwarapa siswa. Jadi dengan itu metode demonstrasi ini siswa dapat berpartisi pasi aktif dan memperoleh pengalaman langsung, dan juga dapat mengembangkan kecakapannya walaupun demikian kita masih melihat juga kelemahan pada metode ini. Peneliti menyimpulkan bahwa pada pembelajaran matematatika yang di ajarkan guru menggunakan metode demonstrasi ini kurang begitu efektif entah dari guru yang kurang dalam penyampaiannya atau memang siwa yang belum begitu paham dengan apa yang dijarkan guru pada saat pembelajaran terebut atau bisa jadi siswa masih merasa bahwa matematika adalah suatu hal yang sulit dan pembelajaran yang idak menyenangkan karna pembelajaran matematika sulit untuk di pahami atau pembelajaran yang diajarkan guru menggunakan metode demontrasi membosankan sehingga anak tidak mau mengikuti pembelajaran matematika dengan serius.

\section{Daftar Pustaka}

Asrori, M. 2012. penelitian tindakan kelas, Bandung : cv wacana prima.

Astuti, T. P. (2013). Perbedaan Kemampuan Matematis Siswa Antara Yang Mendapatkan Model Pembelajaran Snowball Throwing Denga Yang Mendapatkan Model Pembelajaran Numbered Heads Together (NHT). Skripsi STKIP. Garut: tidak di terbitkan

Budiningsih, D. asri. 2012. belajar dan pembelajaran (cetakan 2). Yogyakarta: rineka cipta.

Febriyanto, B., Haryanti, Y. D., \& Komalasari, O. (2018). Peningkatan Pemahaman Konsep Matematis Melalui Penggunaan Media Kantong Bergambar Pada Materi Perkalian Bilangan Di Kelas Ii Sekolah Dasar. Jurnal Cakrawala Pendas, 4(2), 32. https://doi.org/10.31949/jcp.v4i2.1073

Fitriani, K., \& Maulana, -. 2016. Meningkatkan Kemampuan Pemahaman Dan Pemecahan Masalah Matematis Siswa Sd Kelas V Melalui Pendekatan Matematika Realistik. Mimbar Sekolah Dasar, 3(1), 40-52. https:// doi.org/10.17509/mimbar-sd.v3i1.2355

Heruman. 2013. model pembelajaran matematika, Bandung: PT remaja rosda karya. 
Heryanti, V., Bagi, K., Dalam, G., Keguruan, F., Ilmu, D. A. N., \& Bengkulu, U. 2014. Meningkatkan Perkembangan Kognitif Anak Meningkatkan Perkembangan Kognitif Anak.

Hidayat, U. s. 2011. model-model pembelajaran (cetakan 1).Bandung: cv. siliwangi \& CO.

Sari, D. P., Nurochmah, N., Haryadi, H., \& Syaiturjim, S. 2016. Meningkatkan Kemampuan Pemahaman Matematis Melalui Pendekatan Pembelajaran Student Teams Achivement $\begin{array}{llll}\text { Division. Jurnal Riset Pendidikan } & 16 .\end{array}$ https://doi.org/10.21831/jrpm.v3i1.7547

Sugiyono. 2019. metode penelitian kualitatif, kuantitatif dan RnD (M. dr. ir sutopo, S.Pd (ed.); edisi ke 2),Bandung: CV Alfabeta.

Syarifah, L. L. 2017. Analisis Kemampuan Pemahaman Matematis Pada Mata Kuliah Pembelajaran Matematika Sma Ii. Jurnal Penelitian Dan Pembelajaran Matematika, 10(2), 5771. https:// doi.org/10.30870/jppm.v10i2.2031

Tengah, S., \& Demonstrasi, M. (n.d.). Penerapan Metode Pembelajaran Demonstrasi Untuk Meningkatkan Hasil Belajar Siswa Pada Materi Perkalian Bilangan Cacah di Kelas II SDN Inpres 1 Birobuli. 4(4), 284-296. 